\title{
Peningkatan Kemampuan Membaca Menggunakan Media Gambar Siswa Kelas Satu SDN 3 Suralaga Tahun Pelajaran 2019/2020
}

\author{
Baiq Halimatuz zuhrotul Aini \\ Institut Agama Islam Hamzanwadi NW Pancor \\ baiqzuhrotulaini@gmail.com
}

\begin{abstract}
Abstrak
Penelitian ini bertujuan untuk mengetahui Peningkatan Kemampuan Membaca Mengunakan Media Gambar Siswa Kelas 1 Sekolah Dasar Negeri 1 Suralaga tahun pelajaran 2019/2020. Jenis Penelitian ini adalah penelitian tindakan kelas.Subyek penelitian dalam penelitian ini Siswa Kelas 1 Sekolah Dasar Negeri 1 Suralaga tahun pelajaran 2019/2020. Untuk mengumpulkan data hasil kemapuan membaca siswa, digunakan instrument tes kemapuan membaca berdasarkan kriteria dan indikator-indikator yang telah ditentukan..

Hasil penelitian menunjukan : siklus I rata-rata kemampuan membaca siswa adalah 65,85 dan tingkat prosentase ketuntasan mencapai 55\% dengan tingkat kemampuan sedang. Pada siklus II rata - rata kemampuan membaca siswa meningkat menjadi 76 dan tingkat kemampuan sudah tergolong tinggi dengan tingkat ketuntasan mencapai $85 \%$ sesuai dengan target yang telah ditetapkan peneliti yaitu $80 \%$. Berdasarkan hasil analisis data maka dapat disimpulkan bahwa penerapan media gambar dalam pembelajaran dapat meningkatkan kemampuan membaca siswa pada kelas I SDN 1 Suralaga tahun pelajaran 2019/2020.
\end{abstract}

Kata kunci: Pembelajaran Menggunakan Media Gambar, kemampuan membaca siswa. 


\section{PENDAHULUAN}

Pembelajaran Bahasa memiliki peran sentral dalam perkembangan intelektual, sosial, dan emosional siswa yang merupakan penunjang keberhasilan dalam memelajari semua bidang studi.Menyadari peran yang demikian, pembelajaran bahasa diharapkan dapat membantu siswa mengenal dirinya, budayanya dan budaya orang lain, mengemukakan gagasan dan perasaan, berpartsipasi dalam masyarakat yang menggunakan bahasa tersebut, dan menemukan serta menggunakan kemampuan analitis dan imaginatif yang ada dalam dirinya. ${ }^{1}$

Pembelajaran Bahasa Indonesia diarahkan untuk meningkatkan kemampuan siswa berkomunikasi,membaca dan menulis dalam Bahasa Indonesia dengan baik dan benar, baik secara lisan maupun tulis, serta menumbuhkan apresiasi terhadap hasil karya kesastraan masyarakat Indonesia ${ }^{2}$ Bahasa Indonesia diajarkan sejak anak usia dini. Hal ini disebabkan pengajaran tersebut dapat memberikan kemampuan dasar berbahasa Indonesia dengan baik dan benar. Salah satu aspek pengajaran bahasa Indonesia di sekolah dasar yang memegang peran penting adalah membaca, khususnya membaca permulaan.

Membaca permulaan merupakan kegiatan awal untuk mengenal simbolsimbol fonetis. Pada sisi lain, pentingnya pengajaran membaca permulaan pada anak diberikan sejak usia dini ini juga bertolak dari kenyataan bahwa masih terdapat sebelas juta anak Indonesia dengan usia $7-8$ tahun tercatat masih buta huruf. Selain itu, menurut laporan program pembangunan 2005 PBB tentang daftar negara berdasarkan tingkat melek huruf, Indonesia masih berada pada peringkat 95 dari 175 negara.

Pembelajaran bahasa dan sastra Indonesia mencakup empat aspek keterampilan yang harus dimiliki oleh siswa yaitu: keterampilan menyimak, berbicara, membaca dan menulis. Dari empat keterampilan tersebut, salah satu keterampilan yang harus dimiliki adalah keterampilan membaca. Tugas guru tidak

\footnotetext{
${ }^{1}$ Depdiknas “Kamus Besar Bahasa Indonesia Edisi ke - 2".Jakarta : Balai Pustaka. 2005)Hal

${ }^{2}$ Ibid, hal 231
} 317 
hanya menyajikan materi pembelajaran secara keseluruhan, tetapi juga dapat menciptakan kesempatan yang seluas-luasnya kepada para siswa untuk mengunakan media pembelajaran dalam proses pembelajaran.

Observasi yang dilakukan pada siswa kelas satu di SDN 1 Suralaga Kec. Suralaga Kabupaten Lombok Timur, masih banyak siswa yang mengalami kesulitan dalam membaca. Misalnya : membaca teks pendek dengan lafal dan intonasi yang tepat, contohnya saat guru mengucapkan kalimat "Ayah memberiku kado ulang tahun berupa boneka upin ipin ", kemudian para siswa mengulangi kalimat tersebut dengan lafal dan intonasi yang tepat.

Pada kondisi tersebut, dapat diatasi dengan mengunakan media pembelajaran yang bersahabat, meneyenangkan dan tetap bermakna bagi siswa. Untuk itu guru harus memiliki media gambar yang akan digunakan, selain bervariasi tersedia dalam buku-buku dan gambar, pemilihan berbagai warna yang bervariasi juga akan lebih menarik dan membangkitkan minat serta perhatian siswa. Dengan gambar dapat di perbesar bagian-bagian yang penting sehingga siswa lebih mudah memahami apa yang dimaksud berdasarkan uraian diatas.

Berdasarkan hasil observasi ini yang mendorong peneliti untuk melakukan peneliti dengan judul "Peningkatan Kemampuan Membaca Menggunakan Media Gambar Siswa Kelas Satu SDN 1 Suralaga Tahun Pelajaran 2019 / 2020".

Adapun rumusan masalah yang dapat dirumuskan berpijak dari latar belakang masalah, yaitu Bagaimanakah peningkatan kemampuan membaca siswa setelah digunakan pembelajaran mengunakan media gambar pada kelas I SDN 1 Suralaga. Faktor - faktor apa saja yang mempengaruhi peningkatan kemampuan membaca melalui media gambar siswa kelas I SDN 1 Suralaga.

Tujuan dari penelitian ini adalah Untuk mengetahui bagaimanakah peningkatan kemampuan membaca siswa setelah digunakan pembelajaran mengunakan media gambar pada kelas I SDN 1 Suralaga. Untuk mengetahui Faktor - faktor apa saja yang mempengaruhi peningkatan kemampuan membaca Menggunakan media gambar pada siswa kelas I SDN 1 Suralaga. 


\section{METODE PENELITIAN}

Jenis penelitian ini adalah penelitian tindakan kelas yang akan dilaksanakan dalam beberapa siklus. Penelitian tindakan kelas (PTK) adalah bagaimana sekelompok guru mengorganisasikan kondisi praktik pembelajaran mereka sendiri, mereka dapat mencoba suatu gagasan perbaikan dalam praktek pembelajaran mereka dan melihat pengaruh nyata dari upaya itu ${ }^{3}$ Subjek dalam penelitian ini adalah peserta didik kelas 1 semester ganjil SDN 1 Suralaga yang berjumlah 20 orang yang terdiri dari laki-laki 8 orang dan perempuan 12 orang. Alasan memilih subyek penelitian ini adalah bahwa berdasarkan hasil observasi yang di lakukan peneliti lakukan bahwa di kelas 1 tingkat kemampuan membaca siswa dalam aspek menceritakan gambar masih rendah. Siswa merasa kesulitan dalam membaca menceritak gambar di depan kelas .

Pemilihan metode penelitian didasarkan tujuan penelitian. Sementara desain penelitian adalah model atau gambaran bentuk penelitian yang akan diikuti dalampelaksanaan penelitian tindakan kelas ${ }^{4}$. Ada beberapa macam model penelitian tindakan kelas yang dapat digunakan. Model penelitian ini dikemabangkan oleh Kemmis dan Mc Taggart tahun 1988 dari deakin University Australia. ${ }^{5}$ Empat komponen penelitian tindakan kelas yaitu: (1) Rencana (pleaning) guru sebagai peneliti merumuskan rencana tindakan yang akan dilakukan untuk memperbaiki dan meningkatkan proses pembelajaran(2)Tindakan (Action) guru melaksanakan tindakan, berdasarkan rencana tindakan yang telah direncanakan, sebagai upaya perbaikan dan peningkatan atau perubahan proses pembelajaran, prilaku, sikap, dan prestasi belajar siswa yang diinginkan. (3)Pengamatan (Observation) guru mengamati dampak atau hasil dari tindakan yang dilaksanakan atau dikenakan terhadap siswa.(4)Refleksi ( Reflection) guru mengkaji dan mempertimbangakan secara mendalam tentang hasil atau dampak

\footnotetext{
${ }^{3}$ Wiraatmadja, Rochiati. (2009). "Metode penelitian tindakan kelas". Bandung: Remaja Rosdakarya. 2009), hal.13

${ }^{4}$ Muhammad Asrori (2009). "Penelitian Tindakan Kelas". Bandung: CV Wacana Prima.2009), hal 66
} 
tentang tindakan yang dilaksanakan itu dengan mendasarkan pada kriteria yangtelah dibuat.

Teknik pengumpulan data pada penelitian ini adalah: (1) Tes kemampuan Membaca. Tes adalah serempetan pertanyaan atau latihan serta alat lain yang digunakan untuk mengukur keterampilan, pengetahuan intelegensi, kemampuan atau bakat yang dimiliki individu atau kelompok. Tes yang digunakan dalam penelitian ini adalah tes lisan sesuai dengan objek yang diteliti. Dalam penelitian ini, peneliti akan mengukur tingkat kemampuan membaca siswa dengan berbantuan media gambar. (2) Observasi.

Observasi adalah penilaian yang dilakukan melalui pengamatan selama pembelajaran berlangsung.Observasi dilakukan untuk mengumpulkan data kuantitafif dan kualitatif sesuai dengan kompetensi yang dinilain adalah aktifitas guru dan siswa. Aktifitas guru dalam proses belajar mengajar adalah guru berusaha menyampaikan sesuatu hal yang disebut "pesan". Peranan guru yang penting adalah menyusun program pembelajaran, memberi informasi yang benar, memberi fasilitas yang baik, membimbing siswa dalam pemerolehan informasi yang benar, menciptakan suasana bebas berpikir sehingga siswa berani bereksplorasi dalam penemuan dan.berupa pengetahuan, wawasan, keterampilan, atau isi ajaran yang lain seperti kesenian, kesusilaan dan agama.

Instrument yang digunakan pada penelitian ini adalah: Tes kemampuan membaca gambar Tes adalah serempetan pertanyaan atau latihan serta alat lain yang digunakan untuk mengukur keterampilan, pengetahuan intelegensi, kemampuan atau bakat yang dimiliki individu. Tes yang digunakan dalam penelitian ini adalah tes lisan sesuai dengan objek yang diteliti. Dalam penelitian ini, peneliti akan mengukur tingkat kemampuan membaca siswa dalam menceritakan gambar yang telah dibagikan dan menceritakan gambar yang diperoleh per siswa.Adapun format yang digunakan untuk mengambil hasil tes kemampuan membaca siswa dalam menceritakan gambar dapat dilihat pada tabel 01 dibawah ini: 
Tabel 01. Rubrik instrumen kemampuan membaca siswa

\begin{tabular}{|c|c|c|c|c|c|c|c|c|c|c|c|}
\hline \multirow{3}{*}{ No } & \multirow{3}{*}{$\begin{array}{l}\text { Nama } \\
\text { Siswa }\end{array}$} & \multicolumn{9}{|c|}{ Aspek kemampuan membaca } & \multirow[b]{3}{*}{ Tota } \\
\hline & & \multicolumn{3}{|c|}{ keberanian (30) } & \multicolumn{3}{|c|}{ kesesuaian (40) } & \multicolumn{3}{|c|}{ Kelancaran(30) } & \\
\hline & & $\begin{array}{r}\text { Depan } \\
\text { Kelas } \\
(0-15)\end{array}$ & $\begin{array}{l}\text { Tempat } \\
\text { Duduk (0- } \\
\text { 10) }\end{array}$ & $\begin{array}{r}\text { Tidak } \\
\text { Berani } \\
(0-5)\end{array}$ & $\begin{array}{c}\text { SeSuai } \\
(0-20)\end{array}$ & $\begin{array}{c}\text { Kurang } \\
\text { Sesuai } \\
(0-15)\end{array}$ & $\begin{array}{c}\text { Tidak } \\
\text { Sesuai } \\
(0-5)\end{array}$ & $\begin{array}{c}\text { Lancar } \\
(0-15)\end{array}$ & $\begin{array}{c}\text { Kurang } \\
\text { Lancar } \\
(0-10)\end{array}$ & $\begin{array}{c}\text { Sulit } \\
\text { Dimenge } \\
\text { rti (0-5) }\end{array}$ & \\
\hline 1 & & & & & & & & & & & \\
\hline 2 & & & & & & & & & & & \\
\hline 3 & & & & & & & & & & & \\
\hline dst & & & & & & & & & & & \\
\hline
\end{tabular}

Teknik analisis data Dalam penelitian ini, peneliti menggunnakan metode analisis data deskriptif yakni dalam bentuk angka-angka dengan menggunakan perhitungan statistik. Analisis statistik ini merupakan analisis data untuk mencari proporsi, mencari reportase atau ratio dengan berpegang pada standar atau kriteria yang telah ditetapkan. Indikator ketercapaian Kemampuan membaca dengan mengunakan media gambar dapat dikatakan berhasil bila setiap siswa mampu memperoleh nilai 70 ke atas dan secara klasikal mencapai $80 \%$ serta bila siswa mampu aktif untuk menjawab pertanyaan-pertanyaan lisan yang disampaikan dalam kegiatan belajar. 


\section{HASIL PENELITIAN DAN PEMBAHASAN}

Sesuai dengan tujuan penelitian yang telah ditetapkan sebelumnya bahwa penelitan ini bertujuan Untuk mengetahui bagaimanakah peningkatan kemampuan membaca siswa setelah digunakan pembelajaran mengunakan media gambar pada kelas I SDN 1 Suralaga.Dalam upaya meningkatkan kemampuan membaca tersebut ada beberapa aspek keterampilan membaca yang menjadi penilaian peneliti seperti: ketepatan antara bacaan dengan gambar, ketepatan struktur kosa kata, kelancaran, kewajaran urutan bacaan, gaya pengucapan.

Pada siklus I, sesuai dengan perencanan yang telah dibuat yaitu membuat RPP sesuai dengan kompetensi dasar dan standar kompetenisi yang telah ditetapkan, membuat lembar observasi dan membuat format penilaian.

Pada saat pelaksanaan tindakan pada siklus I dengan mengunakan media gambar untuk meningkatkan kemampuan membaca, dalam pembelajaran siswa dibagi gambar dipersiapkan. Pada saat pelaksanaan tindakan peneliti masih menemukan kendala-kendala dalam proses pembelajaran diantaranya: kesiapan dan antusias siswa dalam mengikuti kegiatan belajar mengajar yaitu pada proses belajar mengajar masih cukup banyak siswa yang mengerjakan pekerjaan lain, ragu-ragu dalam membaca di depan teman-temannya.

Observasi terhadap proses pembelajaran yang dilaksanakan pada siklus I fokus penelitiannya yaitu tingkat kemampuan membaca siswa, dan mengisi lembar observasi. Adapun hasil evaluasi dan analisis tindakan yang diperoleh pada siklus I ini adalah dari 20 siswa yang mengikuti tes jumlah siswa yang tuntas 11 orang, yang tidak tuntas 9 orang, nilai tertinggi 80 dan nilai terendah 52, dengan persentase ketuntasan secara klasikal 55\%.

Hasil refleksi siklus I dengan memperhatikan kriteria ketuntasan belajar secara klasikal yang dipersaratkan yaitu $80 \%$, hasil tes kemampuan membaca siswa yang dicapai oleh siswa pada siklus I walaupun berada pada rentang sedang karena mean (nilai rata-rata) 65,85 tersebut berada pada rentangan $61,4 \rightarrow 70,6$. Walaupun berada pada rentang tingkat sedang tetapi 
secara klasikal masih belum mencapai kritreria yang telah ditetapkan. Artinya pada siklus I masih terdapat kekurangan dalam pelaksaan pembelajaran membaca menggunakan media gambar dijumpai ketika pelaksanna tindakan, adapun solusi yang digunakan untuk meningkatkan kemampuan membaca siswa yaitu guru dalam proses belajar mengajar agar bisa mengoptimalkan media gambar untuk memberikan pancingan-pancingan pertanyaan sehingga dengan sendirinya siswa akan tumbuh keberaniannya untuk membaca mengeluarkan pendapat.

Guru diharapkan memberikan kesempatan kepada siswa untuk bebas mengaktualisasikan pengetahuan-pengetahuan yang dimilikinya dan berusaha memberikan perhatian untuk setiap siswa. Dari hasil analisis diatas dengan demikian prosedur tindakan pada siklus I masih harus disempurnaka lagi untuk dilanjutkan pada siklus ke 2 dengan mengaju pada hasil refleksi tindakan I.

Siklus ke 2, pada tahap perencanaan sama dengan pada siklus 1 yaitu membuat RPP, membuat lembar observasi dan membuat format penilaian. Pelaksanan tindakan dialkukan berdasarkan RPP yang telah dibuat dan didasarkan dengaan memperhatikan hasil refleksi terhadap pelaksanaan pembelajaran pada siklus I agar kekurangan-kekurangan yang ditemui pada siklus I tidak terjadi lagi pada siklus 2. Hasil obervasi dan data evaluasi pada silklur I, diupayakan penyempurnan pada persiapan-persiapan tindakan di siklus kedua, hal ini dimaksudkan agar pembelajaran berbicara dapat lebih ditingkatkan kualitasnya sesuai dengan target yang telah ditetapkan.

Prosedur pelaksanaan tindakan pada siklus ke 2 ini sama dengan silkus I. hanya dilakukan perbaikan-perbaikan pada hal-hal yang masih kurang sempurna yang ditemukan pada siklus I berdasarknan hasil observasi dan refleksi pada siklus I yang menjadi perhatian khusus pada siklus ke 2 ini yaitu pola intraksi yang terbangun dalam proses pembelajaran dengan mengunakan media gambar pada siklus 2 ini adalah pola intraksi multi arah. Observasi terhadap proses pembelajaran yang dilaksanakan pada siklus ke 2 fokus penelitiannya sama dengan siklus I yaitu tingkat kemampuan membaca siswa 
dan mengisi format observasi, adapun hasil evaluasi dan analisis yang diperoleh pada siklus 2 ini adalah Pada siklus II ini dari data di atas, nilai tertinggi yang diperoleh siswa adalah 88 dan skor terendah 53 setelah dilakukan penghitungan, maka diperoleh mean $=1556 / 20=78$. dengan persentase ketuntasan secara klasikal $85 \%$.

Refleksi pada siklus ke 2 jika dibandingkan dengan siklus I terjadi peningkatan dalam hal tingkat kemampuan membaca, aktivitas belajar juga yang mengalami peningklatan pada siklus ke 2 terlihat dari perhitungan hasil analisis belajar siswa secara kalasikal pada siklus I 55\% menjadi 85\%.

Hal ini terjadi karena dengan pembelajaran mengunakan media gambar siswa dapat melihat langsung media gambar yang disedikan guru tidak asing bagi mereka dan sering di jumpai dikehidupan sehari - hari, apalagi media ngaitkan materi pembelajaran dengan pengalaman mereka sehari-hari. motivasi instrinsik yang mengidentifikasi tingkah laku seseorang yang merasa senang terhadap sesuatu apabila ia menyenangi kegiatan itu,maka termotivasi untuk melakukan kegiatan tersebut. ${ }^{6}$

${ }^{6}$ Hamzah B.Uno. Teori Motivasi dan Pengukurannya. Jakarta: Bumi Aksara.2102),hal 11 


\section{KESIMPULAN}

Berdasarkan hasil penelitian di atas dapat disimpulkan bahwa kemampuan memebaca siswa dapat meningkat dengan diterapkannya media gambar.Dengan melihat gambar motivasi belajar siswa memiliki tingkat yang lebih tinggi dibandingkan hanya diajarkan secara langsung tanpa mengunakan media gambar.Dan ini sesuai dengan teori jeans Piaget bahwa anak SD berada pada pra operasioanal kongret.Berdasarkan hasil analisi data dan Refleksi yang dilakukan pada siklus ke 2 jika dibandingkan dengan siklus I terjadi peningkatan dalam hal tingkat kemampuan membaca, aktivitas belajar juga yang mengalami peningklatan pada siklus ke 2 terlihat dari perhitungan hasil analisis belajar siswa secara kalasikal pada siklus I 55\% menjadi 85\%. 


\section{DAFTAR PUSTAKA}

Azhar Arsyad, . "Media Pembelajaran”. Jakarta; Raja Grafindo Persada.2006

Asrori Muhammad . "Penelitian Tindakan Kelas". Bandung: CV Wacana Prima.2009

Depdiknas. “Kamus Besar Bahasa Indonesia Edisi ke-2”.Jakarta : Balai Pustaka.2005

Nana Sudjana \& Ahmad Rivai."Media Pengajaran”. Bandung; Sinar Baru Algesindo.2011

Uno,Hamzah. Teori Motivasi dan Pengukurannya. Jakarta: Bumi Aksara.2012

Wiraatmadja, Rochiati. "Metode penelitian tindakan kelas". Bandung: Remaja Rosdakarya. 2009 